\title{
PENGARUH ORIENTASI KEWIRAUSAHAAN TERHADAP KEUNGGULAN KOMPETITIF PADA UKM INDUSTRI KREATIF DENGAN KAPASITAS INOVATIF SEBAGAI FAKTOR MEDIASI DALAM MASA PANDEMIK COVID-19
}

\author{
Louis Utama \\ Universitas Tarumanagara \\ louisu@fe.untar.ac.id \\ Oey Hannes Widjaja \\ Universitas Tarumanagara \\ hannesw@fe.untar.ac.id \\ Yenny Lego \\ Universitas Tarumanagara \\ yennyl@fe.untar.ac.id
}

\begin{abstract}
:
A dynamic business environment that includes entrepreneurs must adapt in order to gain competitive advantage. One thing that must be considered is the entrepreneurial orientation and innovative capacity to increase competitive advantage in companies engaged in the creative industry. The method used is by distributing questionnaires to 30 entrepreneurs who run creative industries in the fashion sector in Tanah Abang Market in order to be sampled. The results show that entrepreneurial orientation and innovative capacity directly and positive influence the company's competitive advantage.
\end{abstract}

Keywords: Entrepreneurial Orientation, Innovative Capacity, Competitive Advantage, Creative Industries

\section{PENDAHULUAN}

Pada keadaan menghadapi masa kenormalan baru dalam pandemic Covid-19, perusahaan harus mampu melakukan inovasi untuk mencapai keunggulan kompetitif. Salah satu usaha yang dapat mengambil peranan dalam keadaan ini adalah industri kreatif. Industri kreatif merupakan jenis industri yang bercirikan pada pada kreatifitas, ketrampilan dan inovasi individu untuk membuat produk yang inovatif yang mampu memberikan keunikan bagi peggunanya. Selain itu diharapkan dapat mampu untuk meningkatkan kesejahteraan dan membuka lapangan pekerjaan yang tengah mengalami penurunan saat masa pandemik ini. 
Sektor industri kreatif sangat mengutamakan kreativitas dan informasi pada sumber daya manusia yang berperan dalam faktor produksi untuk memberikan konstribusi kepada perusahaan khususnya dalam hal inovasi. Sebagian perusahaan di Indonesia secara kualitas masih sulit untuk mencapai keunggulan kompetitif dikarenakan adanya beberapa masalah internal yaitu rendahnya kualitas sumberdaya manusia seperti kurang keterampilan sumber daya manusia, kurangnya pengetahuan mengenai pentingnya orientasi kewirausahaan, dan masih rendahnya penguasaan teknologi dan manajemen, serta minimnya informasi (Kumalaningrum, 2012). Salah satu cara yang dapat digunakan untuk dapat bersaing di pasar diperlukan adanya peningkataan kualitas sumber daya manusia dengan mengasah keterampilannya dan mendorong pengetahuan mengenai orientasi kewirausahaan sebagai salah satu strategi. Beberapa penelitian sebelumnya menunjukkan bahwa orientasi kewirausahaan memberikan pengaruh yang positif pada pengambilan keputusan suatu perusahaan, tetapi pengaruh utama ini kadangkala tergantung pada pasar serta sumber daya yang ada pada perusahaan. Secara khusus (Anderson, Covin, \& Slevin, 2009) menunjukkan bahwa tidak sepenuhnya orientasi kewirausahaan sebagai faktor utama dalam menentukan kinerja perusahaan. Tetapi juga terdapat unsur kapasitas inovatif sebagai pemberi pengaruh dalam penentu suatu keunggulan kompetitif perusahaan. Industri kreatif memerlukan sebuah pengaturan maksimal guna mengetahui hubungan yang potensial antara orientasi kewirausahaan dan kapasitas inovatif pada suatu kinerja di perusahaan. Hal ini dikarenakan perusahaan yang bergerak di industri kreatif bersaing sebagian besar pada kemampuan mereka untuk menumbuhkan ide-ide yang inovatif, kreatif, dan dalam kompetensi artistik yang dihasilkan oleh sumber daya manusia dari perusahaan, serta estetika yang mengarahkan sebuah kompetensi yaitu sebuah peluang pasar yang terbaik seperti, kemampuan perusahaan dalam mengkomersilkan hasil dari kreatifitas yang ada. Inovasi yang harus dihasilkan oleh suatu perusahaan adalah inovasi yang tidak mudah untuk ditiru, memiliki nilai sendiri, dan tidak dapat digantikan nilai tersebut dengan nilai yang lain. Atas dasar hal tersebut, maka 
orientasi kewirausahaan dan kapasitas berinovasi diharapkan mempengaruhi kinerja perusahaan dengan menentukan strategi untuk mencapai suatu keunggulan kompetitif. Dapat diyakini bahwa orientasi kewirausahaan dapat terwujud dalam industri kreatif melalui pendekatan strategis yaitu, otonomi,

\section{TELAAH LITERATUR}

Orientasi Kewirausahaan

Orientasi kewirausahaan merupakan konsep kewirausahaan yang merefleksikan suatu langkah, metode, dan gaya organisasional yang bertindak secara kewirausahaan (Stevenson dan Jarillo,1990). Oleh karena itu perusahaan yang ingin meningkatkan keberhasilan kewirausahaan korporat harus memiliki pandangan orientasi kewirausahaan (Dess dan Lumpkin, 1996). Adanya orientasi kewirausahaan pada perusahaan mencerminkan sebuah kecenderungan di dalam perusahaan untuk ikut terlibat dalam melakukan perilaku yang inovatif, berani mengambil resiko dan bersikap proaktif untuk dapat mengalahkan pesaing yang berada di pasar (Utama dan Nadi, 2017). Jadi kewirausahaan dapat dianggap sebagai produk dari orientasi wirausaha. Proses, praktek dan aktivitas inovasi, pengambilan risiko, proaktif, dan agresivitas kompetitif sedangkan kapasitasi inovasi dapat tercerminkan sebagai faktor mediasi dalam kompetensi kreativitas yang dilakukan masing-masing perusahaan.

pembuatan keputusan (orientasi wirausaha) menghasilkan new entry (kewirausahaan). Orientasi wirausaha mencerminkan kecenderungan perusahaan untuk terlibat dalam perilaku inovatif, berani mengambil resiko dan proaktif untuk mengalahkan pesaing. Perusahaan yang terlibat dalam perilaku semacam ini dapat secara efektif berkembang atau meningkatkan kinerja dan daya saing perusahaan (Lumpkin dan Dess, 1996)

Kapasitas Inovatif

Kapasitas inovatif merupakan suatu keadaan yang mendorong individu untuk mampu mempunyai pemikiran secara kreatif dan dapat mengelola proses secara kreatif pada suatu organisasi sehingga akan muncul sebagai suatu tema yang sentral di dalam strategi kontemporer dan riset pemasaran suatu perusahaan (Powell 
dan Snellman, 2004). Kapasitas inovatif dapat berupa lingkungan dari suatu perusahaan yang mempengaruhi tingkat kreativitas yang dapat memberikan manfaat dalam mendukung kegiatan berinovasi (Hurley dan Huly,1998). Selain itu kapasitas inovatif adalah lingkungan kerja yang dapat membantu untuk meningkatkan kegiatan seseorang dalam berinovasi dengan mengadopsi kebiasaan yang baru yang diterapkan didalam organisasi dan yang melibatkan seluruh aspek di dalam aktivitas organisasi (Ndubisi, 2014). Sehingga kapasitas secara umum adalah sesuatu kegiatan perbaikan dari lingkungan di tempat kerja yang berkelanjutan untuk mendorong seseorang untuk berpikir secara kreatif dan dapat mengimplementasikan sebuah ide untuk menghasilkan suatu inovasi dalam pengembangan suatu produk baru untuk memenuhi kebutuhan yang ada di pasar.

\section{Keunggulan Kompetitif}

Keunggulan kompetitif merupakan hasil dari suatu strategi yang diimplementasikan dengan cara memanfaatkan berbagai jenis sumber daya yang dimiliki oleh perusahaan (Bharadwaj dan Pahy, 1993) . Dengan terdapatnya keahlian karyawan, kemampuan serta aset yang unik maka akan dapat menjadi sebuah pandangan sebagai sumber dari keunggulan dalam bersaing. Hal ini merupakan suatu bentuk strategi yang digunakan untuk membantu perusahaan dalam mempertahankan kelangsungan hidupnya (Day dan Wensley,1988). Pada keadaan pasar yang dalam keadaan bersaing, kemampuan perusahaan menghasilkan kinerja, terutama kinerja keuangan, sangat bergantung pada derajat keunggulan kompetitif suatu usaha (Ferdinand, 2003). Keunggulan kompetitif juga digunakan untuk menilai suatu aspek yang lebih dari hasil kinerja perusahaan dan telah didukung juga oleh banyak temuan yang menunjukkan bahwa kemampuan untuk dapat meningkatkan dan mengeksploitasi suatu kreativitas organisasi berasal dari sumber yang berpotensi kuat dari keunggulan kompetitif (Barney, 1991). Sehingga yang dimaksud keunggulan kompetitif adalah suatu strategi yang dilakukan oleh perusahaan untuk mendapatkan suatu keunggulan dalam hal bersaing di pasar dengan tujuan untuk mempertahankan keberlangsungan hidup. 
Kaitan antara Orientasi Kewirausahaan dan Keunggulan Kompetitif.

Orientasi kewirausahaan merupakan sebuah orientasi yang digariskan oleh perusahaan untuk memiliki sebuah prinsip guna melakukan kegiatan identifikasi dan eksploitasi terhadap peluang yang ada dan apabila perusahaan yang memiliki tingkat orientasi kewirausahaan yang tinggi, akan lebih berani dalam mengambil risiko, dan tidak hanya bertahan pada strategi di masa yang lampau. Orientasi kewirausahaan memiliki tiga dimensi yaitu inovasi, proaktif, dan pengambilan risiko. Inovasi dalam dimensi orientasi kewirausahaan ini cenderung untuk melibatkan dan mendukung pada penciptaan sesuatu yang baru yang dilakukan perusahaan (Lumpkin \& Dess, 1996). Tetapi pada lingkungan yang dinamis, hal tersebut merupakan sebuah variabel yang sangat penting untuk sebuah perusahaan dalam memperoleh suatu keunggulan kompetitif untuk mempertahankan keberlangsungan hidupnya (Schilling, 2006). Orientasi kewirausahaan juga merupakan sesuatu yang dapat mengeksploitasi peluang guna membantu mendorong perkembangan perusahaan (Kumalaningrum, 2012).
Perusahaan yang mempunyai orientasi kewirausahaan dapat mencapai target pasar mereka dan mencapai posisi pasar lebih tinggi, jika dibandingkan dengan para pesaing. Hal ini dikarenakan perusahaan akan bertindak secara proaktif dengan selalu mengamati perubahan yang terjadi di pasar dan melakukan respon dengan cepat terhadap perubahan tersebut. Kemampuan perusahaan yang berani dalam mengambil risiko, juga dapat membuat perusahaan mendapatkan kemampuan dalam menciptakan produk yang baru untuk mendahului para pesaing mereka. Dengan demikian perusahaan akan memiliki suatu keunggulan bersaing, dikarenakan perusahaan mampu untuk mengidentifikasi faktor-faktor yang dapat mempengaruhi permintaan para pelanggan dan memuaskan keinginan para pelanggan.

$\mathrm{H}_{1}$ :Orientasi kewirausahaan berpengaruh terhadap keunggulan kompetitif pada industri kreatif UKM di Pasar Tanah Abang Jakarta 
Kaitan antara Kapasitas Inovatif dan Keunggulan Kompetitif.

Dalam dunia industri kreatif, hal penting di dalam sebuah perusahaan yang paling strategis dan signifikan adalah kreativitas dari organisasi mereka sebagai sesuatu yang merupakan strategi dari manajemen kreativitas dan memiliki potensi dalam memberi pengaruhnya terhadap kesuksesan perusahaan (Thompson, 2007). Kapasitas inovasi adalah suatu keadaan dalam lingkungan kerja yang kreatif sehingga dapat menggunakan sebuah peluang yang akan muncul terutama yang berada di dalam konteks industri kreatif. Perusahaan berfokus kepada penerapan suatu kreativitas yang berada di dalam lingkungan yang kompetitif. Guna mencapai suatu keunggulan kompetitif bagi perusahaan, kreatifitas yang akan dihasilkan oleh perusahaan harus memiliki suatu nilai keunikan tersendiri, tidak mudah diduplikasi, serta tidak mudah untuk digantikan oleh sesuatu yang lain (Schilling, 2006). Dengan adanya tingkat inovasi yang tinggi yang dimiliki oleh individu yang berada di suatu perusahaan akan mampu memberikan ide-ide yang kreatif yang perlu dilakukan agar suatu usaha mampu mendapatkan keunggulan kompetitif di pasar. Sebuah perusahaan harus dapat memiliki tingkat kapasitas inovasi yang tinggi di dalam industri kreatif sehingga dituntut agar dapat membuat sebuah kondisi lingkungan yang dapat mendorong dan mendukung ide-ide kreatif dari penciptaan yang menuju kepada produk, proses, atau suatu sistem yang baru dengan tujuan untuk mendapatkan suatu keunggulan kompetitif di pasar (Szeto, 2000)

$\mathrm{H}_{2}$ : Kapasitas inovatif berpengaruh terhadap keunggulan kompetitif pada industri kreatif UKM di Pasar Tanah Abang Jakarta

$\mathrm{H}_{3}$ : Orientasi Kewirausahaan berpengaruh terhadap keunggulan kompetitif pada industri kreatif pada UKM di Pasar Tanah Abang dengan kapasitas inovatif sebagai mediasi 


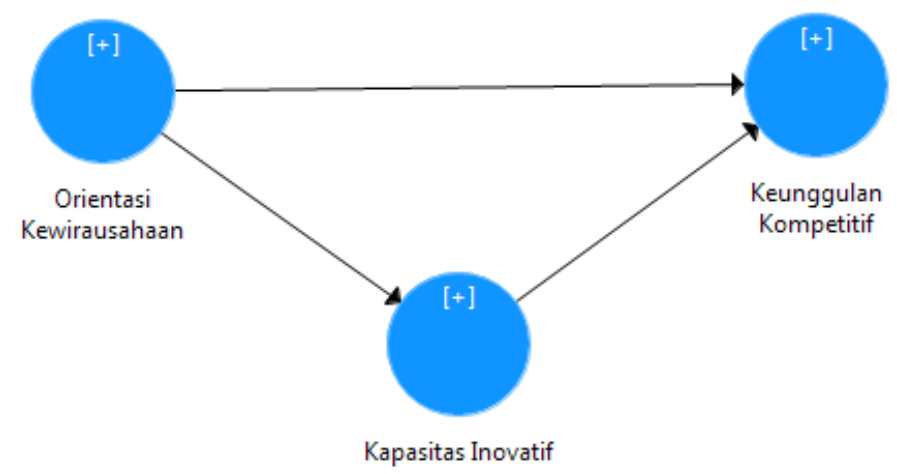

Gambar 1. Model Penelitian

Sumber : Hasil Pengolahan PLS Smart

\section{METODE PENELITIAN}

Pendekatan penelitian yang dipakai dalam penelitian ini adalah pendekatan kuantitatif dengan desain penelitian yang digunakan dalam penelitian ini adalah penelitian konklusif. Dalam penelitian ini, sampel yang akan digunakan adalah usaha kecil mandiri yang bergerak dalam industri kreatif bidang fashion di Tanah Abang, Jakarta pusat yang berlokasikan di Sunter, Jakarta Utara dengan jumlah sampel sebanyak 30 usaha kecil mandiri. Metode yang digunakan dalam teknik pemilihan sampel penelitian ini menggunakan metode non probability sampling. Adapun pertimbangan pemilihan sampel adalah UKM di pasar Tanah Abang, bergerak dalam bidang industri kreatif fashion. Alasan peneliti memilih sampel penelitian pada industri tersebut dikarenakan industri fashion menuntut tingkat inovasi yang tinggi untuk mencapai keunggulan komptetitif dalam lingkungan yang bergerak sangat dinamis. Operasionalisasi variabel orientasi kewirausahaan diambil dengan indikator yaitu kegiatan proaktif, inovasi produk, penciptaan nilai non produk, kegiatan monopoli pasar, strategi biaya rendah, pengecekan proses, tindakan mengatasi masalah, pengambilan risiko, identifikasi peluang, dan risiko kegagalan (Morris \& Sexton, 1996). Untuk variabel kapasitas inovasi didapat dari indikator penerimaan inovasi, ide inovasi dan inovasi perusahaan (Hurley \& Putt, 1998) Sementara variabel keunggulan kompetitif dengan indikator harga terendah, kualitas produk, kemampuan manajerial, dan posisi pasar (Chen, Lai 
\& Wen, 2006). Metode untuk pengumpulan data dalam penelitian ini diambil melalui pembagian kuesioner pada sampel yang telah memenuhi kriteria yang telah ditentukan dan hasil akan diukur menggunakan skala Likert, dengan rentang nilai berkisar antara 1 sampai 5. Data dari kuesioner tersebut lalu diolah lebih lanjut dengan

\section{HASIL DAN PEMBAHASAN}

Subyek pada penelitian ini terdiri dari 40 pemilik Usaha Kecil dan Menengah (UKM) pada bidang industri kreatif yang bergerak dalam dunia fashion di pasar Tanah Abang. Berdasarkan lama menjalankan usaha sebanyak 11 responden atau setara dengan $37 \%$ telah menjalani bisnis keluarga lebih dari 5 tahun. Sebanyak 14 responden atau setara dengan $46 \%$ telah menjalani bisnis keluarga dalam jangka waktu antara 1 sampai dengan 5 tahun. Lalu sebanyak 5 responden atau setara dengan $17 \%$ telah menjalani bisnis keluarga dalam jangka waktu kurang dari 1 tahun. Semua responden merupakan pemilik usaha dan mempunyai konveksi sendiri yang membuat berbagai macam produk fashion dalam industri kreatif. Penjabaran data responden berdasarkan penggunaan model jalur partial least square pada program Smart PLS 3 kemudian dianalisa pengaruh antar variabel untuk melakukan uji hipotesis serta uji mediasi.

karakteristik penjualan tahunan didapatkan sebanyak 26 responden atau setara dengan $87 \%$ memiliki jumlah penjualan tahunan yang berkisar antara Rp 300 Juta sampai dengan Rp 2.5 Milyar. Sebanyak 4 responden atau setara dengan 13\% memiliki jumlah penjualan tahunan yang berkisar antara Rp 50 Juta sampai dengan Rp 300 Juta. Terakhir penjabaran data responden berdasarkan karakteristik jumlah karyawan semua responden memiliki jumlah karyawan berkisar antara 5 sampai dengan 19 orang. Hasil dari Outer loadings (measurement model) atau validitas konvergen Hasil Outer loadings (measurement model) atau validitas konvergen digunakan untuk menguji unidimensionalitas dari masing-masing konstruk. Untuk menguji unidimensionalitas dari masing-masing konstruk nilai indikator 
loading faktor yang lebih besar atau sama dengan 0,5 dapat dikatakan valid. Hasil outer loadings didapatkan dengan nilai terendah sebesar 0,563 dan terbesar sebesar 0,937. Uji keandalan data penelitian ini dilakukan dengan composite reliability., keseluruhan hasil uji berada diatas 0,70. Maka dengan demikian data orientasi kewirausahaan, kapasitas inovasi dan keunggulan kompetitif adalah reliabel dan terandalkan dan dapat dipergunakan untuk uji hipotesis. Nilai adjusted $R$ square adalah variabel lain yang dapat menunjukkan kesesuaian keseluruhan model regresi. Dalam model regresi penuh, untuk Keunggulan kompetitif, didapatkan adjusted $R$-square sebesar 0.750 menunjukkan bahwa dalam full model dapat menjelaskan, masing- masing, $75 \%$. Untuk menilai uji Goodness of Fit (GoF) pada suatu penelitian, sebelumnya peneliti harus mengetahui nilai AVE pada penelitian tersebut. $\overline{A V E}$ adalah 0,5853 . Untuk nilai $\overline{R^{2}}$ adalah sebesar 0.767 maka nilai GoF sebesar: $G o F=\sqrt{\overline{A V E} \times \overline{R^{2}}}=$ $\sqrt{0,5853} \times 0,767=0,67$. yang berarti nilai atau tingkat kelayakan model penelitian ini dapat dinyatakan besar, berdasarkan teori nilai GoF yang dinyatakan oleh Tenenhaus (2004) yaitu nilai GoF dibagi menjadi tiga kategori yaitu, kecil $=0,1$, sedang $=0,25$, besar $=0,38$. Karena uji R-Square, dan GoF telah memenuhi syarat maka selanjutnya dapat dilakukan uji hipotesis (lihat tabel 1).

Tabel 1. Hasil Pengujian Hipotesis

\begin{tabular}{lccc} 
& Original sample & T Statistik & P Values \\
$\begin{array}{l}\text { Orientasi } \\
\text { Kewirausahaan }\end{array}$ & 0.824 & 14.691 & 0.000 \\
Kapasitas Inovatif & 0.166 & 1.801 & 0.072 \\
\hline
\end{tabular}

Sumber : Hasil Pengolahan PLS Smart

Dalam full model untuk keunggulan kompetitif dengan variabel independennya yaitu orientasi kewirausahaan dan kapasitas inovasi memberikan hasil yang signifikan yaitu berturut turut nilai signifikansinya 0.000 , dan 0.072 yang mendukung hipotesis $\mathrm{H}_{1}$ dan $\mathrm{H}_{2}$. Dari hasil 
siginifikansi ini dapat dikatakan bahwa semakin besar orientasi kewirausahaan dan kapasitas inovatif yang dimiliki oleh perusahaan, semakin besar kemungkinan perusahaan akan dilengkapi dengan keungguan kompetitif. Hal tersebut sesuai dengan penelitian yang telah dilakukan oleh Anderson, Covin \& Slevin (2009), Lee (2001), Baker, W.E. and Sinkula, J.M. (2009) tentang orientasi kewirausahaan dengan memberikan hasil orientasi kewirausahaan memiliki pengaruh yang signifikan terhadap keunggulan kompetitif perusahaan. Oleh karena itu wirausahawan harus dapat menerapkan orientasi kewirausahaan dengan maksimal untuk dapat meningkatkan keunggulan kompetitif. Penerapan orientasi kewirausahaan tersebut dapat dilakukan dengan sebuah inovasi yang menarik terhadap suatu produk dan juga dapat menciptakan nilai tidak hanya terhadap produk tetapi kepada non produk. Wirausahawan mampu berani dalam pada sikap pengambilan resiko terutama yang berguna untuk mengembangkan sebuah produk serta layanan menjadi lebih baik lagi. Salah satu cara yang dapat diambil adalah dengan strategi berbiaya rendah dengan tetap mengedepankan mutu yang mampu menciptakan suatu keagresivitas kompetitif yang baik sehingga usaha yang dikelola tersebut mampu mendominasi pasar. Pemilik usaha diharapkan selalu bersikap proaktif untuk mengetahui perubahan apayang terjadi dalam lingkungannya sehingga dapat mengambil keputusan dengan baik, maka pengembangan produk dan layanan yang diberikan terhadap pelanggan dapat diterima dengan baik dan mampu membuat suatu keunggulan kompetitif. Hasil dari pengujian hipotesis yang kedua menunjukan bahwa pengujian kapasitas inovatif terbukti berpengaruh secara signifikan terhadap keunggulan kompetitif. Hal ini sesuai dengan penelitian yang telah dilakukan oleh Calantone, R., Cavusgil, S. T., \& Zhao, Y. (2002), Weerawardena, J. (2003) tentang kapasitas inovatif yang menghasilkan kapasitas inovatif memiliki pengaruh yang signifikan terhadap keunggulan kompetitif perusahaan. Wirausaha seharusnya menerapkan kapasitas inovasi secara maksimal guna meningkatkan keunggulan kompetitif usaha. Penerapan kapasitas inovatif dapat dilakukan dengan cara membangun suasana lingkungan kerja yang meembuat tiap individu yang 
berada di perusahaan untuk cenderung dapat berpikir secara kreatif sehingga mampu untuk menghasilkan lebih banyak ide kreatif guna menciptakan nilai tambah pada suatu produk lebih baik dibanding pesaing agar perusahaan memiliki keunggulan kompetitif yang lebih dibanding pesaing.

Tabel 2. Hasil Pengujian Mediasi

\begin{tabular}{ccc} 
& T. Statistik & $P$. Values \\
OK -> KI -> KK & 1.526 & 0.128 \\
\hline
\end{tabular}

Sumber : Hasil Pengolahan PLS Smart

Pada penelitian ini ditemukan bahwa pengaruh orientasi kewirausahaan pada keunggulan kompetitif dalam konteks industri kreatif tidak mampu dimediasi oleh kapasitas inovatif. Hal ini dimungkinkan bahwa efek langsung dari orientasi kewirausahaan terhadap keunggulan kompetitif dinilai lebih baik. bukti pentingnya kemampuan manajerial perusahaan dalam melihat peluang dan mengarahkan strategi perusahaan yang paling mengeksploitasi

\section{SIMPULAN DAN SARAN}

Penelitian menunjukkan bahwa menghasilkam beberapa temuan yaitu pentingnya suatu orientasi kewirausahaan dalam mengenali peluang untuk menciptakan nilai dari sebuah produk maupun non produk dalam sebuah perusahaan dan juga organisasi dengan kreatif. Selain itu bukan hanya kehadiran individu kreatif yang menghasilkan keunggulan kompetitif pada perusahaan dimana seharusnya pihak manajemen perusahaanlah yang harus memilih di antara semua peluang yang ada pada setiap pasar untuk mengarahkan sumber daya kreatif sehingga peluang yang paling baik meningkatkan keunggulan kompetitif perusahaan (Ray et.al., 2004)

peran dari kapasitas inovatif yang dapat berhasil memanfaatkan peluang tersebut dengan baik. Implikasi dari hasil penelitian ini adalah walau terdapat wirausahawan pada industri kreatif secara implisit mengakui pentingnya variabel orientasi kewirausahaan (inovasi, bertindak proaktif, da 
pengambilan risiko) di dalam sebuah perusahaan terkadang melupakan talenta kreatif yang dapat dikembangkan dari pemikiran apa yang harus dilakukan untuk menghadapi tahap kenormalan baru dari sumber daya yang ada. Sektor industri kreatif dapat mengambil manfaat dari mengadopsi kerjasama antar sumber daya guna menciptakan keseimbangan hasil yang kreatif dan layanan yang baik guna menghasilkan produk yang lebih baik dan bersifat unik disbanding pesaing untuk mencapai keunggulan kompetitif. Penelitian ini menyarankan bahwa penerapan orientasi

\section{DAFTAR PUSTAKA}

Anderson, B., Covin, J., \& Slevin, D. (2009). Understanding the relationship between entrepreneurial orientation and strategic learning capability:An empirical investigation. Strategic Entrepreneurship Journal 3(3), 219-241.

Baker, W., \& Sinkula, J. (2009). The Complementary Effects of Market Orientation and Entrepreneurial Orientation on Profitability in Small Businesses. Journal of Small Business Management, Vol. 47, No 4, p.443-464.

Barney, J. (1991). Firm resources and sustained competitive advantage. Journal of Management, 17, 99120. kewirausahaan bersamaan dengan pengembangan kemampuan inovasi perusahaan dapat menghasilkan hasil yang baik. Hasil ini dapat berguna bagi wirausahwan yang bergerak dalam industri kreatif untuk berinvestasi dalam kemampuan kreatif yang akan membantu mengarahkan kompetensi kreatif dan artistik perusahaan mereka ke arah keunggulan kompetitif yang lebih baik selain itu dengan diciptakannya produk inovatif maka akan dapat membuka lapangan pekerjaan baru pada tahap kenormalan baru.

Bharadwaj, P.R, S., \& Pahy, J. (1993). Sustainable Competitive Advantage in Services Industries:A Conceptual Model and Research Propositions Vol 57. Journal of Marketng, 83-100.

Calantone, R., Cavusgil, S., \& Zhao, Y. (2002). Learning orientation, firm innovation capability, and firm performance. Industrial Marketing Management, 21(6), 515-524.

Day, G., \& Wensley, R. (1988). Assessing Advantage: A Framework for Diagnosing Competitive Superiority. Journal of Marketing, 52 (April), 1- 20. 
Ferdinand, A. (2003). Sustainable Competitive Advantage: Sebuah Eksplorasi Model Konseptual. Semarang: Badan Penerbit Universitas Diponegoro.

Hurley, R. F., \& M., H. G. (1998). Innovation, Market Orientation, and Organizational Learning: An Integration and Empirical Examination. Journal of Marketing, 62, 42-54

Kumalaningrum, M. P. (2012). Lingkungan Bisnis, Orientasi Kewirausahaan,Orientasi Pasar dan Kinerja Usaha Mikro,Kecil dan Menengah. Jurnal Riset Manajemen dan Bisnis Volume 7, No. 1 Juni.

Lee, C. L. (2001). Internal capabilities, external networks, and performance: a study on technology-based ventures. Strategic Management Journal, 22(6-7), 615-640.

Lumpkin, G., \& Dess, G. G. (1996). Clarifying the entrepreneurial orientation construct and linking it to perfomance. Academy of Management Review, 21(1), 135172.

Ndubisi. (2014). Entrepreneurship and Service Innovation. Journal of Business\&Industrial Marketing, no 29, 449-453.

Powell, W., \& Snellman, K. (2004). The Knowledge economy. Annual Review of Sociology, 30, 200-220.

Schilling, M. (2006). Game Not Over:Competitive Dynamics in the Video Game Industry,in Lampel, Shamsie\&Lant (Eds.).
The Business of Culture.Mahwah,NJ:LEA

Associates.

Stevenson, H., \& Jarillo, J. (1990). A paradigm of entrepreneurship:Entrepreneurial management. Strategic Management Journal (Special issue)11, 17-27.

Szeto, E. (2000). Innovation capacity: Working towards a mechanism for improving innovation within an inter-organizational network. The TQM Magazine, 12(2), 149157

Ray, G. Barney J.B. \& Muhanna WA. (2004). Capabilities, business processes, and competitive advantage: choosing the dependent variable in empirical tests of the resource-based view. Strategic Management Journal, 25(1): 23-37

Thompson, P., Jones, M., \& Warhurst, C. (2007). From conception to consumption: creativity and the missing managerial link. Journal of Organizational Behaviour, 28. 625-540

Utama, Louis \& Nadi, Jeremy Kristanto. 2017."Pengaruh Kreativitas terhadap Kinerja Usaha dengan Orientasi Kewirausahaan sebagai Mediasi pada Wirausaha di ITC Cempaka Mas". Conference on Management and Behavioral Studies. Universitas Tarumanagara Jakarta. 12 Oktober 2017. Hal. 80-88. 
Weerawardena, J. (2003). Exploring The Role of Market Learning Capability in Competitive
Strategy. European Journal of Marketing, Vol. 37,p. 407-429 